\title{
CORPORATE SOCIAL RESPONSIBILITY. EXAMPLE ROŞIA MONTANĂ GOLD CORPORATION
}

\author{
Vasile Burja ${ }^{1}$ \\ Silvia - Ştefania Mihalache ${ }^{2}$
}

\begin{abstract}
Corporate Social Responsibility, a concept without a world accepted definition is starting to be used in Romania as well. This is the reason why in the present article we try to make a theoretical description of the present concept and to exemplify it by presenting the responsible activities of a corporation in Romania, Roşia Montană Gold Corporation.
\end{abstract}

Key words: corporate social responsibility, stakeholder, social impact

JEL codes: M14, Q01.

\section{Introduction}

Taking birth on the most liberal market in the world, in the United States of America, somewhere in the 60's (Carroll, 1999) and adopted with great enthusiasm in Europe, after two decades, the concept of corporate social responsibility is gradually taken by the Romanian business environment.

Most specialty analysts consider that the conceptual foundations of corporate social responsibility were established by Andrew Carnegie, in his essay "The Gospel of Wealth" in 1899. It is considered that Carnegie is the one who established the principle of charity, according to which the people who became rich through their business have the obligation to support the less fortunate members of society. Carnegie believed that wealthy businesses and individuals should use the money they possess as some reliable managers for the rest of the community, also multiplying the social wealth through prudent investment. This second principle stated by Carnegie is known as the principle of responsible management.

Considered a strange concept as it brings into question one of the central premises of capitalism - the idea according to which the main purpose of business is to make profit for owners/shareholders. The emphasis is not positioned only on the state, until recently this being the only one that would have "to give", but also on the economic agents, agents that following the globalization's course and the society's need to protect the human and environmental dimension, begin to act as an active member of this society. Thus, transnational corporations become the promoters of this phenomenon of awareness of the traders' need to engage both indirectly, as before, but especially directly, in the life of the society giving the corporate social responsibility a transnational and global dynamics. Therefore one can easily conclude that this concept of corporate social responsibility is closely related to globalization and the society's need to preserve the human and environmental resources.

This global dynamic of CSR phenomenon may give the impression of a lack of importance of the national dynamics concerning this phenomenon, but recent studies show that the phenomenon manifests itself differently depending on the economic, social, cultural, legal and political context in which it takes place (Matten and Moon, 2004).

CSR is a globalized concept, disseminated through regional and international institutions and through the chains of distribution/supply of transnational companies. Once the time passed this

\footnotetext{
1 “1 Decembrie 1918” University of Alba Iulia, E-Mail: vasileburja@yahoo.com

2 “1 Decembrie 1918” University of Alba Iulia, E-Mail: sylvia_mihalache@yahoo.com 
concept has earned an honorable place management culture, CSR representing a part of a company without which it cannot be considered modern and legitimate. As such, this concept follows the dynamic of international management trends through their inclusion in the European and international standards.

In fact, for the managers of globalized business world, CSR has become an acronym which can hardly be avoided. Specifically, all transnational companies in the world are some way involved in CSR activities, some authors even considering that there is no country where businessmen have not accepted the CSR challenge in any way (Hennigfeld, 2006).

Also, investors are starting to be aware of the fact that the activities that integrate social concerns in the company's strategies and actions are part of what some people call "good management" (Hohnen, 2007). Moreover, in order to enhance the image of reliability in the community and to attract quality customers and employees, acting responsibly towards the people who work and the rest of the society can create value both for the companies and for the society in which they operate and whose members they are.

A thing worth mentioning is that CSR is a constantly evolving concept and it seems that it has no universally accepted definition. In general, the concept of corporate social responsibility is understood as the way in which companies introduce social, environmental or economic concerns in their values, strategies and decision making operations, in a transparent and responsible manner, thus establishing best practices in company, assuring the health and improving the society's existence conditions (Hohnen, 2007). With the emergence of sustainable development concept and acknowledging its importance, the question of how business environment deals with this issue has become an element of social responsibility.

However, we cannot neglect the fact that many companies are not responsible towards society in general, but only towards their stakeholders, many times this being realized mainly to minimize the negative effects that the activity has and maximize the positive effects of activity undertaken on some identified problems. For this case there are countless examples, from companies producing cosmetics to food producers.

CSR covers a wide range of issues such as: environment, sustainability, human rights, business ethics and corruption, labor law, competition, trade, sanctions, export controls, antiterrorism initiatives, donations etc.

Above all, CSR is about sensitiveness to a context - both social and environmental - and is directly related to performance. It refers to moving from the stage of declared intentions to concrete actions, effective and observable with a measurable impact on society. Also, reporting the performances is part of the company's transparent, credible and responsible conduct. The possibility that problems occur is very high if the involved stakeholders perceive a company as being unable to demonstrate concrete actions leading to real environmental and social benefits.

Corporate social responsibility can only occur where the company is aware that it is a part of the society, it is considered a member of that society, and as a consequence it should act as such and furthermore, the company must be aware of the impact that it has on the environment, society and economic activity which it carries out. It is important that social responsibility is perceived as being more then charity, donations or planting trees, it is much more than that. Contemporary economy is based on social and environmental models whose mysteries were revealed over time through experiences and observations. Thus, a shock in any part of the social, economic or environmental status quo can affect the whole system.

Current economic situation and, in particular, the global financial crisis unfortunately show that after more than one hundred years, the principles set by Carnegie in his essay "The Gospel of Wealth" remain an unachievable goal. Unwise speculation made to maximize the profits exposed the global economy to unacceptable risks and have thrown into poverty a large number of employees, households and small businesses, without attracting severe implications for those responsible for this situation. 
However, it is gratifying that the ISO 26000 International Standard on social responsibility is in an advanced stage of preparation and will soon become (in 2010) a global reference not only for corporations but for any other type of organization. Most likely it will include the lessons of previous initiatives which have been implemented by major international organizations such as: the United Nations, the Organization for Economic Cooperation and Development or the European Union. The standard creates a comprehensive framework for guiding the efforts of organizations to integrate social responsibility through strategy and practical actions. The principles supported by this standard refer to: accountability, transparency, ethical behavior, respect towards the stakeholders' expectations, respect the law, respect for the international standards of behavior and respect for human rights; principles that apply in the following key areas: organization's governance, human rights, working relations, environment, fair business practices, consumer's issues, community involvement and support for its development.

With regard to CSR in Romania, the nearest, relevant and available example is Roşia Montană Gold Corporation, a highly controversial project because the activities to be conducted, and especially the technologies that are desired to be used in the mining of precious metals. Below, we will see how the RMGC project tries to be responsible towards the society where it carries out its activities. The reasons why the RMGC Company uses these responsible activities can be very different, from softening the local community to making a diversion and drawing attention from the project's negative impact. We will see how many of the responsible activities planned by the company will be concluded in a positive way.

\section{Motivation, the importance of the theme and the methodology used}

This present paper intends to be a theoretical study of the corporate social responsibility concept and its implementation in the reality of Romanian society. For this, the data were gathered from authorized sources, bibliographic materials from the internationally recognized databases were used and was initiated a research about the way in which strategies, policies and activities specific for corporate social responsibility are used and how to apply them within the RMGC project according to official reports of the company.

Due to the increased importance of the social responsibility in the globalized business world, companies are advised to become more responsible about the impact of their activities on the environment and beyond, and also to meet the needs and expectations of their stakeholders. Often, this social responsibility is used as a means of diversion and of promoting the company, many company managers using these strategies to divert attention from the harmful effects of manufactured and sold products.

The purpose of this research is to highlight the economic and especially the social impact of the RMGC proposed project, a project aimed at achieving a gold and silver mining in the area of Roşia Montană, Romania and also to study how corporate social responsibility is reflected in the RMGC project, the way in which its specific activities are carried out, and how the information about CSR undertaken activities is transmitted and perceived.

In order to achieve this purpose at first, was presented the theoretical concept of corporate social responsibility, its features, specific activities, principles, CSR models, the factors leading the companies to implement CSR activities and Romanian CSR practices and initiatives, then the descriptive lines of the Roşia Montană project were drawn by highlighting the way in which RMGC achieves corporate social responsibility in the project proposed by them.

\section{A conceptual approach of the corporate social responsibility}

As ethical and ecological consumerism movements mature, companies and their promoters are advised to be more responsible when it comes to the impact of their activities on the environment, on the society they belong to; an appropriate example is that of the ISO 26000 international standard which would be published, as a recommendation, somewhere in May this 
year.

Movements that promote social responsibility will be able to impose more and more obligations for companies so they will respect their status as a member of the society. Some companies will try to resist these new requirements, giving up only when the law will oblige them to be responsible. But the companies with progressive views will voluntarily offer to accept the responsibility for the world around them. The latter are those that see responsible actions as the possibility to survive by doing well. They are those looking for ways to obtain profits by the longterm orientation towards the customer, towards his needs (Kotler et al., 2008).

\section{Concept}

Although very often used in theory, but especially in practice, the concept of "corporate social responsibility" can not be considered as having a generally valid and accepted definition. Thus, the World Business Council for Sustainable Development uses the following definition: "Corporate Social Responsibility is the continuous commitment of an enterpriser (a business) to behave ethically and to contribute to the economic growth, implicitly helping to improve living conditions, raising the living standards for the workforce and their families as well as for the local community and for society, in general."

In the United States, the investigated concept is traditionally defined merely as a philanthropic model. The companies obtain a profit and do not meet any obstacle as long as they pay their taxes. In their case, social responsibility is summed up to donate a part of the profit for a noble/charity cause, without claiming to get a profit from this move.

However, the European model focuses more on the company's business development as responsible as possible, being completed by community investment. This European model is considered more sustainable because: social responsibility is an integrating part of wealth creation which, if properly managed, should strengthen the business environment, increase its competitiveness and maximize the creation of value for society. Therefore, it can be concluded that there is not a model of social responsibility that can be applied to all companies in the world, and there is no generally accepted definition for this concept.

Another example of definition, this time the definition used by the Business for Social Responsibility company (a leader in corporate responsibility that has created, together with other 250 companies, a network for creating sustainable management strategies through consultation, research and intra-sector collaboration) is that social responsibility is "business management in a way that it meets or even exceeds the ethical, legal, commercial expectations or the expectations that the community has from a company."

Furthermore, the European Commission uses the following definition: "a concept whereby companies voluntarily decide to contribute to the society's development and to a healthy living environment. A concept whereby companies voluntarily integrate social and environmental concerns into their operational strategies and the interaction with the directly involved stakeholders."

\section{The ten principles of UN Global Compact}

In an address to World Economic Forum on January 31, 1999, United Nations GeneralSecretary, at the time, Kofi Annan, has challenged the leaders of companies to join the international initiative - UN Global Compact - that would bring together companies, UN agencies, civil society and labor organizations to support universal environmental and social principles.

UN Global Compact initiative was launched at UN headquarters in New York on July 26, 2000. Presently, more than 5,200 companies from all regions of the world, including international organizations of civil society and labor organizations are involved, acting to promote the ten principles of universal principles from domains such as: human rights, labor standards, environment and fighting corruption. 
In the light of collective action's power, this initiative aims to promote corporate social responsibility so that companies can take part in solving the problems induced by globalization. Therefore, it is considered that the private sector - in partnership with other social stakeholders - can help to achieve the UN General Secretary's vision that is to create a global economy more sustainable and inclusive.

As the definitions of social responsibility induce the idea of volunteering, so the UN Global Compact represents a purely voluntary initiative and is based on two major goals: implementing the ten principles in the companies' businesses worldwide, and catalyzing action to support the UN overall objectives. In achieving these objectives, UN Global Compact provides facilities and commitments through several mechanisms: Policy Dialogues, Case Study (Learning), National/Regional Networks Projects.

UN Global Compact is not a regulatory or enacting instrument - the initiative does not control, supervise or monitor the companies' conduct or actions, as the ISO 26000 international standard won't be; they are only recommendations for companies intending to use them. It rather relies on public accountability, transparency and the responsible interests of companies, of civil society and of labor organizations in order to initiate and share key activities for achieving the promoted principles.

The 10 principles of UN Global Compact on human rights, labor standards, environment and fighting corruption enjoy the universal approval and are derived from: the Universal Declaration of Human Rights, ILO Declaration on Fundamental Principles and Rights at Work, Statement of Rio on Environment and Development, United Nations Convention against Corruption. Thus, the UN Global Compact recommends companies to incorporate, support and take within their sphere of influence a set of core values on human rights, labor standards, environment and fighting corruption.

Therefore, the first two principles are found in human rights domain: the first principle claims that companies should support and respect the protection of internationally proclaimed human rights and that they must ensure that they are not companion in human rights abuse cases. This latter recommendation represents the second principle promoted by the UN Global Compact.

The next four principles are part of the labor standards and they support the companies to encourage freedom of association and actual recognition of the right to collective negotiations, the fourth principle supports the elimination of all forms of forced or compulsory labor, the fifth principle concerns the effective abolition of child labor, and the sixth principle eliminates the discrimination in respect of employment and occupation.

The environment is the third area in which the main recommendations for companies are set out. Thus, through the principle number seven, companies are recommended to support a precautious approach to ecological problems, to carry out promotion actions for a higher level of environmental responsibility (principle eight) and to encourage the development and spread of compatible ecological technologies (ninth principle).

The tenth, and last principle, refers to fighting corruption, namely, companies must fight against all forms of corruption, including bribery and extortion.

\section{CSR Models}

According to specialty literature, three models of CSR have outlined over time: CSR socioeconomic model, characterized by two dimensions, namely the company's responsibility duration and the range of results from the company's social commitments ( $\mathrm{Zu}, 2009)$. As one can see, this is a model whose obvious goal is to obtain profit, just like in the case of any other economic activity. A second model would be CSR stakeholder model. This model is based on the fact that a business's success, positive or negative, is directly related and influenced by stakeholders. Thus, it is understood that the shareholders' needs can not be met without complying, to a certain extent, the 
stakeholders' needs (Jamali, 2008). The third CSR mode, called Triple Buttom Line Model is built on the idea according to which the ultimate success of a corporation can and should be measured not only traditionally, on the financial line, but also with the help of its ethical and environmental performance $(\mathrm{Zu}, 2009)$.

Factors leading companies to implement CSR actions/measures:

Any economic agent, regardless of the carried out activity, is influenced in his decisions by a number of variables; this is also true for CSR activities. Thus, in a consumerist society, the first determining factor is the ethical consumerism, because the pressure exercised by the rational use of limited natural and non-renewable resources increases proportionally with the number of global population in the continuous effort to meet the consumers' needs. The latter are becoming more attentive to how the consumption induces social and environmental implications. A second factor determining a company to be responsible is the globalization and market power. These stimulate the companies to use CSR as a strategic tactic to obtain a public support for their presence on the world's markets, this helping them to maintain a competitive advantage by using their social contributions to feed the advertising at the level of consumers' subconscious.

Particularly important is the ethical training of the employees in order to minimize the negative incidents from the company or because of the company's employees. Over recent years, companies have become increasingly interested in any methods that might increase the visibility and popularity among consumers to whom they address, that is why even the respecting of in force laws, regulations and recommendations for different domains, the most relevant example being the EU recommendations for ISO 26000, could represent a process that increases company's popularity. Unfortunately, there are those crises and their consequences that attract special attention from economic agents. In this case, a handy example is the Mattel Company that produces toys and which was forced to withdraw millions of toys from the market and to initiate new risk management and quality control processes. Another example is the company Magellan Metals in Australia which was responsible for the deaths of hundreds of birds in the region where it operated and which has ceased production and began a broad campaign of greening the area. Basically, the corporations are motivated to become socially responsible because they know that their stakeholders expect them to understand and consequently address the priorities and needs of a society of whose members they are; the stakeholders' priorities representing also a key factor for companies' CSR activity.

\section{Research on CSR model adopted by RMGC}

Roşia Montană Gold Corporation Company (RMGC) has the following capital distribution: 80\% Gabriel Resources Ltd (Canada), 19.31\% Deva Copper Autonome Régie (later Mininvest), $0.23 \%$ three minority stakeholders (Cartel Bau, Foricon Co. and Comat Co.).

The mai objective of the project proposed by RMGC is to develop a gold and silver mine and is located near the village of Roşia Montană, in Alba County, $80 \mathrm{~km}$ from Alba Iulia. Mining activities will be conducted in four open careers (Cetate, Cârnic, Orlea and Jig), exploitable reserves are estimated at $215 \mathrm{Mt}$ ore containing $1.46 \mathrm{~g} /$ tone gold and $6.9 \mathrm{~g} /$ tone silver recovered metals, the total production is estimated at $247.7 \mathrm{t}$ ( 7.9 milions ounces) gold and $898.5 \mathrm{t}$ ( 28.9 milions ounces) silver.

Project costs are valued at 3.703 million U.S. dollars of which 2.523 million will be spent in Romania. Direct benefits related to the Romanian state from taxes and dividends amount to 985 million dollars, and the company's estimated profit is over 1.4 billion U.S. dollars.

The mining project will be developed in four distinct phases: pre-construction, construction, operating period, and the period of closing the project.

These stages generated the need to address the economic impact, and especially the social one following the dynamic of the projects. Thus: the first step, foreseen to be completed in three years time, targeted the following objectives: continuous exploration of deposits; support for Minvest to close the current mine exploitation, decrease the environmental impact resulting from 
mining activities conducted in the past; financing activities; obtaining the necessary agreements and permits for mining; activities of detail design; auctions for design and management contract(s) for construction; property acquisition and land transfer agreements necessary for the project's development, protecting and materializing the cultural and historical heritage, relocation and removal activities, support for planning the local and regional development; coordination with relevant stakeholders.

The major impact on the area during this period is the one related to properties acquisition, displacement and relocation of the population in the area. These activities will have a social impact, primarily affecting the local population. Some consequences will be positive in that the displaced or relocated population will receive compensation amounts, above the market value previous then the start of the project for owned properties and in the future, they will be able to live to higher standards. On the other hand, of course that displacement and relocation will have negative consequences requiring the change of many families' lives, affecting the local community cohesion, psychological implications towards local commitment etc.

The late start of the project will increase the burden on the local population, most of the properties being already purchased, the construction of the infrastructure needed for relocation will be delayed, there is a state of uncertainty which can create local tensions.

The second stage, i.e. the period of construction, will last between two and three years, the main activities of this period being: building the removal infrastructure by using mainly local manufacturers and suppliers, displacing or relocating the people affected by the project, preparing the site for the future pits, opening and exploiting the future pit that will provide building materials for roads, concrete etc., closing or developing the existing exploitation on the project's site, connection to high voltage electricity network, building a water pipeline from the Arieş River, building a new access road to Roşia Poieni, building the Corna Valley mud-setting pond and the second retention dam, construction of the Cetate dam to collect the acidic waters in Roşia Valley, building the WWTP (wastewater treatment plant) of acid mine waters, building the water treatment plant and a wastewater treatment plant for domestic sewage.

The impact of this stage on the area is obvious. The construction of the site necessary for relocation is an opportunity for the people who will benefit from the new location to live in modern houses with access to utilities and services to the highest standards. A series of permanent facilities which the local community or other investors will use after the project is over will also be developed. Construction activities are an opportunity for the companies in the area to develop their business and they provide additional employment opportunities for local people.

The third stage, i.e. the exploitation one, which is expected to be carried out for over 16 years, consists of conventional exploitation activities of ore quarry (drilling, blasting, loading, transportation), its preparation and processing, and its economic impact on the area will be felt primarily by the incomes from wages of employed people who will help increase the living standards of people in the impact area. These incomes will be mainly spent throughout the area and this offers new opportunities for business development and therefore new employment. Also, the company's connections with the firms in the area will increase since they will provide materials, fuels, services. Company's revenues paid to local and central state budget are substantial and they create financial resources for the overall development of the local community and national economy.

Project's finishing period will begin in the 14th year of the exploitation and will be continued two years after the end of the project having the following the objectives: protecting public health and social welfare, land's geotechnical stabilization, landscape restoration, protecting the quality of life, decommissioning the installations that can not be used anymore, handing over the facilities and some relevant equipment to local authorities and economic agents etc.

It is important that through the closing activities will be provided the conditions for the environmental rebuilding of the area and will be provided the possibility to use it in new economic 
and social activities according to sustainable development requirements.

Besides the activities in the project and presented within the four stages, the company conducts other CSR activities and it is involved in developing the community in terms of encouraging the business environment in the area, by changing the perception about the benefits of an active investment behaviuor. The opening of Roşia Montană Microcredit institution (2006) implicitly contributes to the diversification of economic development and obtaining future sustainable benefits within the local community, important objectives of the current rural strategy developed at national and European level. Thus, Roşia Montană Microcredit is a part of the company's initiative for Community Development, which prepared a comprehensive program of sustainable development. Before granting the credit, the future entrepreneurs benefit of a precursory stage, a Training Programme which mainly aims at helping them to identify the type of business that meets the regional needs, the instruments needed to start the business or to know the basic elements of a business plan meant to substantiate their future economic activity, and not least of advisory services in financial, legal, administrative and organizational issues in order to improve the economic effects of taken decisions.

To summarize, the RMGC company, the initiator of microfinance activity has the following objectives aimed at local sustainable development: stimulating the persons looking for a job, strengthening small businesses, sustaining the discharged people to become entrepreneurs if they have an initial amount with which they can start a business, stimulating the development of economic environment by encouraging the private sector.

Another CSR activity developed within the RMGC project and worthy of consideration is that of the education and training activities development. Some of the measures taken in this regard are in accordance with the rules proposed and imposed by the European Community for Development and Training, which covers a wide range of skills, specialties, starting from areas related to secretarial-office activity, computer, human resources, inspector for labour's protection to the strict professional qualifications for jobs as: trade worker, cook, carpenter, security guard, electrician, excavation man, iron smith, stoker, plumber, bricklayer, welder, piler man, etc. According to the company, during 2006 - 2007, a total of 1389 people have benefited from training courses organized by RMGC. RMGC also provided grants to schools in the area through direct sponsorship. The schools that have received corporate sponsorships include: Bistra Secondary School, Câmpeni Forestry School Group, HCC Highschool of Abrud, "Avram Iancu" National College of Câmpeni, "Simion Balint" General School in Roşia Montană, "Dorin Pavel" Technical College of Alba Iulia etc.

Not lastly, we must mention the RMGC company's also responsible initiative to create a public-private partnership. In this regard we outline a few directions of this partnership: consultating the citizens about important decisions relating to project, specific agreements with local governments in order to support some of their initiatives, collaborating with the educational institutions in the area by providing them material and financial support, collaborating with other socio-cultural institutions in the area (churches, houses of culture, community centers, dispensaries, police, firefighters), collaborating with NGOs in the region, consulting the civil society through authorized representatives for identifying the problems of the local community and help the people, collaborating with the business environment in the region in order to identify and address some common interest issues for ensuring sustainable development of the area.

Among these partnerships we should mentioned the following: Roşia Montană Environmental Partnership aims at raising public awareness about the importance of a clean environment and participation in solving the problems related to this goal of all stakeholders in the region: local authorities, schools, economic agents, NGOs; The Partnership for Biodiversity is closely connected to the environmental partnership and aims to restore the ecological balance and biodiversity of local systems of flora and fauna that have been seriously affected by human activity; the Roşia Montană Reforestation Programme compensates for the alteration of the 246 ha of forest 
land assigned for the implementation of the RMGC project. About 335 hectares of land in Roşia Montană and surroundings will reforested with valuable species (spruce, plane tree, willow, black pine, maple and fir); Roşia Montană Education Partnership aims to improve the educational activity in the communities affected by the Roşia Montană mining project and it is for young people who are direct beneficiaries of the educational act, but also for their teachers; "Good Neighbor" Partnership, is intended to maintain the social cohesion and to help vulnerable people. Beyond the effective social aid, the partnership is built in the spirit of subsidiarity, i.e. to mobilize the internal resources of the community and each family to ensure the material and financial means necessary for the daily life; Partnership for Roşia Montană Cultural Heritage aims at the research, conservation and materialization of the rich cultural heritage from Roşia Montană. Thus, the premises for the development of cultural tourism are created; Roşia Montană Socio-Economic Research Center includes a network of socio-economic specialists who collaborate to identify and address socio-economic problems in the area; the Partnership for developing the touristic potential of the area is one of the important objectives pursued by RMGC in terms of sustainable development of the area. The natural and anthropogenic heritage of the area may be materialized without the existence of an adequate infrastructure, without an adequate marketing and entrepreneurship and with the lack of qualified personnel in the field. All this can be achieved only with significant financial resources that could be drawn towards private-public partnership.

There are other partnerships in which the RMGC Company is involved, but not so width as those listed above. These include: APELL Center helping the community to be aware of the risks; Roşia Montană Environmental Monitoring Programme; the Programme of Hydro-chemical Modeling of Mureş River, CERT Apuseni, Roşia Montană Summer School Programme, Roşia Montană Professional and Vocational Training Programme; Roşia Montană Business Development Partnership, Roşia Montană Watch.

An essential dimension of CSR that concerns the project proposed by RMGC aims at protecting the historical and cultural heritage of the area. For this it is considered the observance of the current legislation, the conservation and valuing the heritage of the existing domain. In this respect, there were carried out archaeological discharge activities, conservation and restoration activities of historic buildings and "Historic Center" protected area of Roşia Montană, research activities, conservation, restoration, valuing and maintenance of historical galleries. The funds that the company is going to provide in the coming years, in order to continue these actions, are about $\$$ 14 million.

To promote this project, RMGC uses all available media, from reports regularly published on the company's websites, to advertising materials on all national channels. In all these communication materials, the stress is on the responsible activities that the company wants to undertake; the homepage of Gabriel Resources website (whose predominant color is green) presents the ten principles (in the page they are called truths) guiding the company, accompanied by a suggestive photo, that is: responsible mining (a green leaf), Best Practices (EU flag), partnership (map), community (the panorama of a village with the church spire in the middle), standards (latest monster truck), good governance (a crowd of people listening), sustainable opportunity (field of flowers), region's culture (a potter), environment (a waterfall), the long view (the globe). Thus, if you add all of these to the social responsibility's features and principles you can easily see that they are respected. And in terms of visitor welcoming message, this is: "partnership for economy, environment, for culture in community", a clear and responsible message, as a member of society should be.

\section{Conclusions}

Presenting the theoretical concept of corporate social responsibility, trying to give some definitions and drawing the lines of some CSR models that were outlined over time by the specialists in the field, followed by the presentation of Roşia Montană Project, we have tried to 
highlight what the social responsibility is as well as how and why it is used. Having at hand all necessary information to do so, we could only conclude that RMGC uses CSR in an almost "aggressive" way.

The company uses all media to inform about the project's objectives: media, Internet, written media etc. It seems that the corporate social responsibility is the most powerful weapon used both for defense against the enemy, represented by numerous NGOs that want to ban the implementation of this project and as offensive weapon used to promote the project and gain the stakeholders' support by shifting their attention from the negative impact that the project can have environmentally and socio-culturally speaking.

\section{References}

1. Blowfield, M., 2005. Corporate social responsibility - the failing discipline and why it matters to international relations, International Relations, 19(2), 173-191.

2. Carroll, A. B., 1999. Corporate social responsibility. Evolution of a definitional construct. Business and Society, 38(3), 268-295.

3. Gjølberg, M., 2009. Measuring the immeasurable? Constructing an index of CSR practices and CSR performance in 20 countries, Scandinavian Journal of Management (2009) 25, $10-22$.

4. Jamali, D., 2008. A Stakeholder Approach to Corporate Social Responsibility: A Fresh Perspective into Theory and Practice, Journal of Business Ethics.

5. Kotler, P., Armstrong, G., 2008. Principiile marketingului, Forth Edition, Teora, Bucureşti.

6. Matten, D., Moon J., 2004. <Implicit> and <Explicit> CSR. A conceptual framework for understanding CSR in Europe, ICCSR Research Paper Series. ICCSR.

7. $\mathrm{Zu}, \mathrm{L} ., 2009$. Corporate Social Responsibility, Corporate Restructuring and Firm's Performance. Empirical Evidence from Chinese Enterprises, Springer-Verlag Berlin Heidelberg.

8. Research project, 2007. Studiu privind impactul economic şi socio-cultural al proiectului Roşia Montană, available in the "1 Decembrie 1918" University of Alba Iulia Library.

9. OECD Guidelines for Multinational Enterprises 2008, available online at http://www.oecd.org/daf/investment/guidelines, data 14.04.2010

10. http://ec.europa.eu/enterprise/csr/index_en.htm - Official Site of European Commission.

11. http://www.wbcsd.org - Official Site of World Business Council for Sustainable Development.

12. http://www.responsabilitatesociala.ro/ce-este-csr.html.

13. http://www.rmgc.ro/landing/index.php.

14. http://www.gabrielresources.com/home.htm.

15. http://www.rosiamontana.ro/.

16. http://www.euractiv.ro/uniunea-europeana/articles/categoryID_61/CSR.html. 